\title{
A CONSEQUENCE OF ACCURATE RECORDS MANAGEMENT ON WORKERS PRODUCTIVITY
}

\author{
Dr. C K GOMATHY, Mr. DARAM NAGA SAI KALYAN, Mr. ADDEPALLI SAI MANI DEEP, Mr. \\ CHALLA SAI HEMANTH \\ Sri Chandrasekharendra Saraswathi Viswa Mahavidyalaya, Kanchipuram
}

\begin{abstract}
:
The case of safe keeping of records is significant to a pot, generally depends on the kinds of a record document used. It was revealed that an electronic form was appropriated. The homemade train system is outdated, on the contrary, an utmost association uses the micro filming as a way of record preservation. An effective operation of records improves associations effectiveness and productivity also as reduces organizations operating an expenditure. The objects of this extended essay thus are to corroborate whether an association indeed has full and acceptable knowledge on record keeping. Having considerably to imagine what the experimenter is each about. It's the experimenter 's belief that the study is getting to be of immense benefits to an office professional and records operation or any association especially handling a record.
\end{abstract}

\section{KEYWORDS:}

Status of records management, records keeping, managing public records, effectiveness of record workers.

\section{I.INTRODUCTION}

Public and private associations need information to serve duly and acceptable record operation must be maintained for proper deciding. Tedesco and Robert (2006) defined record operation as the appliance of scientific control for creating, recycling, filling, maintaining, guarding and removing an association's records so that they are going to be planted when demanded within the shortest period of time and at the smallest cost. Record operation originates from the first men who wrote on stores and walls in cases for the end of unborn references. This information was written in kind of delineation and jotting of languages on walls. As time went on, slates were discovered and knowledge was written and stored on them. Later, there came the use of papers which made the keeping and transfer of knowledge easier, from then, lines were being created to make sure the simple bracket of papers. Within the early 20th century, filing outfits like boxes, closets, bookshelves, trolleys, filing servers, racks and the importance of others kept arising. These were all constructed at different times as long as they were seen to be applicable for the bracket of varied kinds of information.

\section{EXISTING SYSTEM}

Over time, poor records management can cause these systemic issues: Excessive amounts of your time are wasted sorting through messy filing cabinets. Valuable office space is employed to store paperwork, forcing the corporation to pay premium prices for document storage. Files are misplaced, buried, and lost. Ultimately, Records Management ensures that institutional records of important historical, fiscal, and legal value are identified and preserved, while non-essential records are discarded during a timely manner according to established guidelines and identified legislation.

\section{PROPOSED SYSTEM}

The general objective of the study is to seek out the possible impact of poor records to an organizational manager's overall efficiency. To determine how record management affects organizational productivity. To find out how records management affects office managers efficiency. to find out whether the records management contributes to saving of labour, cost and time of the office manager. To ascertain the 
strategies for correct record management that brings about efficiency.

\section{IV.IMPLEMENTATION}

The researchers made use of primary data including the questionnaires. The researchers also made use of secondary data, which were obtained from books, handouts and seminar papers. All the finished questionnaires were also collected personally by the researchers. That is, there's a $100 \%$ return rate. The questionnaires were personally distributed to the respondents. The respondents got time to fill the questionnaire and were collected after one week. The data were analysed by the mean values of the respondents' responses based on the cut-off point obtained from the values allocated to the 4-point scale. The formula for the cut-off point is:

\section{$\sum \mathrm{fx}$}

The four-point scales are represented by the following values:

Strongly Agree

Agree

$\begin{array}{ll}- & 4 \\ - & 3 \\ - & 2 \\ - & 1\end{array}$

Strongly Disagree

$\sum \mathrm{fx}=(4+3+2+1) / 10=2.5$

Any scale less than the cut-off means rejected and any scale on the cut-off point and above is accepted.

Each value of the scale is multiplied by $\mathrm{x}$ to get ( $\mathrm{fx}$ ) for each of the variables was obtained by dividing the sum of the frequency.

Where:

\begin{tabular}{|c|c|c|}
\hline $\mathrm{X}$ & $=$ & The value of each scale \\
\hline $\mathrm{f}$ & $=$ & Frequency for each variable \\
\hline $\mathrm{N}$ & $=$ & Number \\
\hline & $=$ & Summation \\
\hline & $=$ & $\begin{array}{l}\text { Frequency } \\
\text { lue of scale }\end{array}$ \\
\hline
\end{tabular}

\section{V.RESULTS}

In what ways does record management affect organizational productivity?

\begin{tabular}{|l|l|l|l|l|l|l|l|}
\hline $\begin{array}{l}\text { S/ } \\
\text { N }\end{array}$ & Variables & $\begin{array}{l}\text { S } \\
\text { A }\end{array}$ & A & D & $\begin{array}{l}\text { S } \\
\text { D }\end{array}$ & $\begin{array}{l}\text { Me } \\
\text { an }\end{array}$ & $\begin{array}{l}\text { Remar } \\
\text { ks }\end{array}$ \\
\hline 1 & $\begin{array}{l}\text { It } \\
\text { provides } \\
\text { evidence } \\
\text { in the } \\
\text { court of } \\
\text { law }\end{array}$ & 9 & 2 & 2 & 1 & $\begin{array}{l}2.9 \\
9\end{array}$ & $\begin{array}{l}\text { Accep } \\
\text { ted }\end{array}$ \\
\hline 2 & $\begin{array}{l}\text { It leads to } \\
\text { proper } \\
\text { appropria } \\
\text { tion of } \\
\text { funds }\end{array}$ & 9 & 2 & 1 & 7 & $\begin{array}{l}3.3 \\
4\end{array}$ & $\begin{array}{l}\text { Accep } \\
\text { ted }\end{array}$ \\
\hline 3 & $\begin{array}{l}\text { Referenc } \\
\text { e from } \\
\text { records is } \\
\text { used to } \\
\text { proffer } \\
\text { solutions } \\
\text { to } \\
\text { manageri } \\
\text { al } \\
\text { problems }\end{array}$ & 9 & 4 & 3 & 2 & $\begin{array}{l}3.5 \\
1\end{array}$ & $\begin{array}{l}\text { Accep } \\
\text { ted }\end{array}$ \\
\hline 4 & $\begin{array}{l}\text { It aids the } \\
\text { executive } \\
\text { s in } \\
\text { making } \\
\text { decisions }\end{array}$ & 9 & 5 & 5 & 3 & $\begin{array}{l}3.0 \\
0\end{array}$ & $\begin{array}{l}\text { Accep } \\
\text { ted }\end{array}$ \\
\hline
\end{tabular}

No: 115

Cut-off point: 2.5

Based on the table above it was accepted that Proper record management provides evidence in the court of law because the mean value of 2.99 is greater than the cut of point of 2.5.

The second variable was accepted that proper record management leads to proper appropriation of funds; its mean value of 3.34 is accepted as it is greater than the cut off point of 2.5 .

The third variable which states that references from records are used to proffer solutions to managerial problems was accepted 
with a mean value of 3.51 which is greater than the cut-off point of 2.5 .

The fourth variable was also accepted that proper records management aids the executives in making decisions was accepted because its mean value of 3.00 is greater than the cut-off point of 2.5.

Table 2:

In what ways does record management affect Workers Efficiency?

Respondent's response on ways by which record management affects office managers efficiency.

\begin{tabular}{|c|c|c|c|c|c|c|c|}
\hline $\begin{array}{l}\mathrm{S} \\
\mathrm{N}\end{array}$ & Remarks & $\begin{array}{l}\mathrm{S} \\
\mathrm{A}\end{array}$ & $\mathrm{A}$ & $\mathrm{D}$ & $\begin{array}{l}S \\
D\end{array}$ & $\begin{array}{l}\mathrm{Me} \\
\text { an }\end{array}$ & $\begin{array}{l}\text { Remar } \\
\text { ks }\end{array}$ \\
\hline 1 & $\begin{array}{l}\text { It prevents } \\
\text { losing of } \\
\text { essential } \\
\text { documents }\end{array}$ & $\begin{array}{l}9 \\
1\end{array}$ & 9 & 8 & 7 & $\begin{array}{l}3.3 \\
5\end{array}$ & $\begin{array}{l}\text { Accep } \\
\text { ted }\end{array}$ \\
\hline 2 & $\begin{array}{l}\text { It enables } \\
\text { easy } \\
\text { location of } \\
\text { documents }\end{array}$ & $\begin{array}{l}7 \\
7\end{array}$ & $\begin{array}{l}1 \\
3\end{array}$ & $\begin{array}{l}1 \\
7\end{array}$ & 7 & $\begin{array}{l}3.1 \\
4\end{array}$ & $\begin{array}{l}\text { Accep } \\
\text { ted }\end{array}$ \\
\hline 3 & $\begin{array}{l}\text { Saves } \\
\text { office } \\
\text { managers } \\
\text { time and } \\
\text { effort }\end{array}$ & $\begin{array}{l}8 \\
9\end{array}$ & $\begin{array}{l}1 \\
1\end{array}$ & $\begin{array}{l}1 \\
2\end{array}$ & 3 & $\begin{array}{l}3.0 \\
6\end{array}$ & $\begin{array}{l}\text { Accep } \\
\text { ted }\end{array}$ \\
\hline 4 & $\begin{array}{l}\text { Prevents } \\
\text { misappropr } \\
\text { iation of } \\
\text { funds }\end{array}$ & $\begin{array}{l}9 \\
4\end{array}$ & 6 & 7 & 8 & $\begin{array}{l}3.6 \\
9\end{array}$ & $\begin{array}{l}\text { Accep } \\
\text { ted }\end{array}$ \\
\hline 5 & $\begin{array}{l}\text { Enhance } \\
\text { the ability } \\
\text { of the } \\
\text { office } \\
\text { manager to } \\
\text { keep } \\
\text { confidential } \\
\text { documents }\end{array}$ & $\begin{array}{l}8 \\
0\end{array}$ & $\begin{array}{l}2 \\
1\end{array}$ & 9 & 5 & $\begin{array}{l}2.9 \\
1\end{array}$ & $\begin{array}{l}\text { Accep } \\
\text { ted }\end{array}$ \\
\hline
\end{tabular}

No: 115

Cut-off point: 2.5

\section{VI.CONCLUSION}

Based on the info analysed from the findings of the study the subsequent conclusions were received. The findings also conclude that proper record management affects the office manager's efficiency by enabling the office manager's ability to stay confidential documents and also prevents misappropriation of funds. The findings conclude that as a result of proper record management, organizations' time cost and labour is saved because proper record management results in the achievement of setting goals as well as making information available within a really short time. Finally, the researchers concluded that record management brings about efficiency within the system and advised organizations to lay more emphasis on proper record management and always update their record management department.

\section{VII.REFERENCES:}

1.Dr.C K Gomathy, Article: A Study on the recent Advancements in Online Surveying, International Journal of Emerging technologies and Innovative Research ( JETIR ) Volume 5 | Issue 11 | ISSN : 2349-5162, P.No:327-331, Nov-2018

2.Dr.C.K.Gomathy,C K Hemalatha, Article: A Study On Employee Safety And Health Management International Research Journal Of Engineering And Technology (Irjet)- Volume: 08 Issue: 04 | Apr 2021

3. Dr.C K Gomathy, Article: A Study on the Effect of Digital Literacy and information Management, IAETSD Journal For Advanced Research In Applied Sciences, Volume 7 Issue 3, P.No-51-57, ISSN NO: 2279-543X,Mar/2018

4. Dr.C K Gomathy, Article: An Effective Innovation Technology In Enhancing Teaching And Learning Of Knowledge Using Ict Methods, International Journal Of Contemporary Research In Computer Science And Technology (Ijcrcst) EIssn: 2395-5325 Volume3, Issue 4,P.No-10-13, April '2017

5.Dr.C K Gomathy, Article: Supply chain-Impact of importance and Technology in Software Release Management, International Journal of Scientific Research in Computer Science Engineering and 
Information Technology ( IJSRCSEIT ) Volume 3 | Issue 6 | ISSN : 2456-3307, P.No:1-4, July-2018

\section{Author's Profile: -}

1.

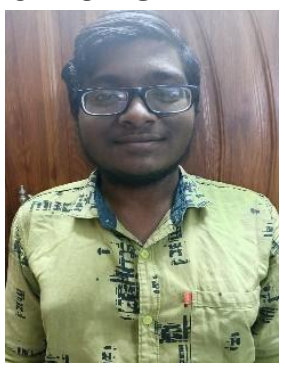

Mr. Addepalli Sai Mani Deep, Student, B.E. Computer Science and Engineering, Sri Chandrasekharendra Saraswathi Viswa Mahavidyalaya University deemed to be university, Enathur, Kanchipuram, India. His Area of Big data analytics.

2.

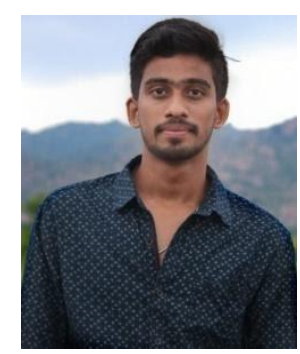

Mr. Daram Naga Sai Kalyan, Student, B.E. Computer Science and Engineering, Sri Chandrasekharendra Saraswathi Viswa Mahavidyalaya University deemed to be university, Enathur, Kanchipuram, India. His Area of Big data analytics.

3.

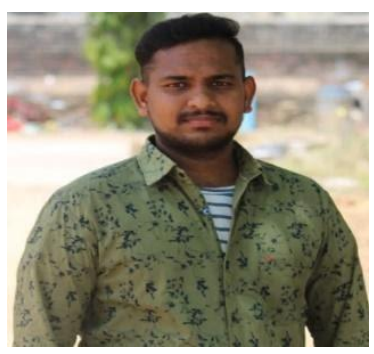

Mr. Challa Sai Hemanth, Student, B.E. Computer Science and Engineering, Sri Chandrasekharendra Saraswathi Viswa Mahavidyalaya University deemed to be university, Enathur, Kanchipuram, India. His Area of Big data analytics.

4.

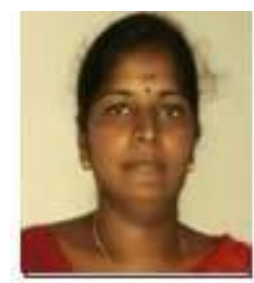

Dr.C.K. Gomathy is Assistant Professor in Computer Science and Engineering at Sri Chandrasekharendra SaraswathiViswa Mahavidyalaya deemed to be university, Enathur, Kanchipuram, India. Her area of interest is Software Engineering, Web Services, Human Resource,Knowledge Management and IOT. 